\title{
25 Research Square \\ Incidence and Risk Factors Associated with Human Albumin Administration Following Total Joint Arthroplasty.
}

\section{Shaoyun Zhang}

Sichuan University West China Hospital

Haibo Si

Sichuan University West China Hospital

Jinwei Xie

Sichuan University West China Hospital

Yuangang Wu

Sichuan University West China Hospital

Qinsheng Hu

Sichuan University West China Hospital

Yi Zeng

Sichuan University West China Hospital

Fuxing Pei

Sichuan University West China Hospital

Bin Shen ( $\nabla$ shenbin_1971@163.com )

Sichuan University West China Hospital

\section{Research}

Keywords: risk factor, human albumin, hypoalbuminemia, total hip arthroplasty, total knee arthroplasty.

Posted Date: March 1st, 2021

DOI: https://doi.org/10.21203/rs.3.rs-259876/v1

License: (1) (1) This work is licensed under a Creative Commons Attribution 4.0 International License. Read Full License 


\section{Abstract}

\section{Background}

Human albumin (HA) administration is associated with an increased risk of acute renal failure and most other complications in patients undergoing total hip or knee arthroplasty (THA, TKA). Therefore, it is vital to reduce the use of HA and identify risk factors for its use. This study aims to determine the incidence and risk factors of HA administration in patients undergoing THA or TKA.

\section{Methods}

We identified patients undergoing THA or TKA in multiple institutions from 2014 to 2016 and collected patient demographics and perioperative variables. The criterion of HA administration was defined as a postoperative albumin level $<32 \mathrm{~g} / \mathrm{L}$ or 32 to $35 \mathrm{~g} / \mathrm{L}$ for at-risk patients. We compared 14 variables between patients who received $\mathrm{HA}$ administration and those who did not after stratification by the preoperative albumin (pre-ALB) level. Multivariate regressions identified the independent risk factors associated with HA administration.

\section{Results}

In total, $958(20.3 \%)$ of 4713 patients undergoing THA and 410 (9.7\%) of 4248 patients undergoing TKA received $\mathrm{HA}$ administration. In addition to pre-ALB $<35 \mathrm{~g} / \mathrm{L}$, preoperative anemia (odds ratio [OR] 2.12, $\mathrm{P}=$ 0.001; OR 1.39, $\mathrm{P}<0.001)$ and drain use (OR 3.33, $\mathrm{P}=0.001 ; \mathrm{OR} 4.25, \mathrm{P}<0.001)$ were also independent risk factors for HA administration after THA regardless pre-ALB $<35 \mathrm{~g} / \mathrm{L}$ or not, and patients undergoing TKA diagnosed of rheumatoid arthritis or ankylosing spondylitis tended to receive HA administration regardless pre-ALB $<35 \mathrm{~g} / \mathrm{L}$ or not $(\mathrm{OR} 3.67, \mathrm{P}=0.002 ; \mathrm{OR} 2.06, \mathrm{P}<0.001)$.

\section{Conclusion}

The incidence of HA administration was high in patients undergoing THA or TKA, and several variables were risk factors for $\mathrm{HA}$ administration. This finding may aid surgeons in preoperatively identifying patients requiring $\mathrm{HA}$ administration and optimizing perioperative managements.

\section{Introduction}

Total joint arthroplasty (TJA) is a successful orthopedic procedure and the full numbers increase year by year [1]. Along with changes of the payment models, it is more and more necessary to reduce postoperative complications and shorten the length of stay [2]. Malnutrition, especially hypoalbuminemia $(<35 \mathrm{~g} / \mathrm{L})$, has been found to be an important predictor of complications after total hip arthroplasty (THA) or total knee arthroplasty (TKA) [3], and interventions have also shown that improved albumin levels can reduce the incidence of complications and thus reduce costs $[4,5]$. 
To reduce the incidence of postoperative complications, several studies have recommended patients delay elective TJA until hypoalbuminemia correction $[3,6]$. There are ways to increase albumin levels through amino acid supplementation [4], high protein diets [5], and human albumin (HA) administration [7], but it turns out that HA administration is the fastest and most effective. However, HA administration may also increase the risk of anaphylaxis, renal insufficiency, and cardiac complications, especially for elderly patients with TJA, as well as increased costs $[8,9]$. In a retrospective study conducted by Opperer et al [8], a total of 1051,441 patients undergoing THA or TKA in 510 US hospitals were included, the results showed perioperative $\mathrm{HA}$ administration was associated with an increased risk of acute renal failure (odds ratio [OR] 1.56, 95\% confidence interval [CI] 1.36-1.78), thromboembolic complications (OR $1.47,95 \% \mathrm{Cl} 1.16-1.87$ ), cardiac complications (OR 1.37, 95\% $\mathrm{Cl} 1.19-1.57$ ), and pulmonary complications (OR 1.82, 95\% Cl 1.58-2.10) comparing with patients who did not receive. Therefore, measures need to be taken to avoid unnecessary HA administration.

A previous study found that female patients, with long operation time, and with low preoperative albumin (pre-ALB) levels were associated with a higher likelihood of HA administration, but the total sample size was too small and only 16 patients received HA administration [10]. Thus, this large multicenter study was performed to determine the real incidence of HA administration in patients undergoing THA or TKA. Furthermore, 14 independent variables were collected and identified to find the risk factors for HA administration in our study. It is hypothesized that patients with low pre-ALB levels undergoing THA or TKA were more likely to receive HA administration.

\section{Methods}

\section{Study design and participants}

A retrospective analysis of data collected on patients undergoing primary or revision THA or TKA in multiple institutions from 2014 to 2016 through the National Health Database [11]. Patients were excluded if they had missing data on preoperative serum albumin level, or important demographic characteristics (Fig. 1).

This study was approved by the hospital's institutional review board $(2012-268)$.

No informed consent was required since the data are anonymized.

The criterion of HA administration was determined by dietitians and surgeons, which was set as a postoperative albumin level of $<32 \mathrm{~g} / \mathrm{L}$ or $32-35 \mathrm{~g} / \mathrm{L}$ but with lack of appetite or incision exudation [5]. After stratification by the surgical site (THA or TKA), patients were grouped into those with pre-ALB $<35$ $\mathrm{g} / \mathrm{L}$ and those who with pre-ALB $\geq 35 \mathrm{~g} / \mathrm{L}$. The potential variables associated with HA administration including patient demographic characteristics such as age, sex, and body mass index (BMI), and perioperative factors were all collected and analyzed. Perioperative factors included diagnosis, American Society of Anesthesiologists (ASA) class, preoperative anemia, surgical type, anesthesia, tourniquet use (for TKA), anticoagulant use, tranexamic acid use, colloid solution use, drain use, and transfusion use. 


\section{Statistical analysis}

Pearson chi-square test or Fisher exact test was used for categorical variables to assess the differences of proportions between the HA and non-HA groups. A forward LR model for multivariate logistic regression analysis was used to examine independent risk factors for HA administration. ORs, corresponding $95 \% \mathrm{Cls}$, and p values were computed. A p-value of < 0.05 was considered statistically significant. Due to 14 clinical variables were evaluated, a conservative Bonferroni p-value was computed as $0.05 / 14$ for the significance of multivariate regression [12]. All analyses were performed using IBM SPSS version 24.0 .

\section{Results}

Of 9283 initial patients, 8961 (96.5\%) met inclusion criteria (Fig. 1). Among them, 4713 (52.6\%) patients undergoing THA, whereas 4248 (47.4\%) undergoing TKA, were included. There were 958 (20.3\%) patients received $\mathrm{HA}$ administration and 441 (9.4\%) patients with pre-ALB $<35 \mathrm{~g} / \mathrm{L}$ in THA group, while 410 (9.7\%) patients received HA administration and 207 (4.9\%) patients with pre-ALB $<35 \mathrm{~g} / \mathrm{L}$ in TKA group.

The results of the comparison of demographic characteristics and perioperative factors between $\mathrm{HA}$ and non-HA groups in patients undergoing THA or TKA are shown in Additional file 1: Table S1 and S2, which were greatly influenced by differences in pre-ALB levels. Thus, after stratified by pre-ALB levels, we compared those again in these patients. For patients undergoing THA, HA administration was associated with diagnosis, preoperative anemia, anesthesia, anticoagulant use, and drain use in those with pre-ALB < $35 \mathrm{~g} / \mathrm{L}(\mathrm{P}<0.05)$, which was associated with age, sex, diagnosis, ASA class, preoperative anemia, surgical type, anesthesia, anticoagulant use, colloid solution use, and drain use in those with pre-ALB $\geq$ $35 \mathrm{~g} / \mathrm{L}(\mathrm{P}<0.05)$ (Table 1). For patients undergoing TKA, HA administration was associated with BMI and diagnosis in those with pre-ALB $<35 \mathrm{~g} / \mathrm{L}(\mathrm{P}<0.05)$, which was associated with diagnosis, preoperative anemia, surgical type, anesthesia, colloid solution use, and drain use in those with pre-ALB $\geq 35 \mathrm{~g} / \mathrm{L}$ ( $\mathrm{P}<$ 0.05) (Table 2).

After that, multivariate logistic regression analyses were conducted to identify independent risk factors for HA administration in patients undergoing THA with pre-ALB $<35 \mathrm{~g} / \mathrm{L}$ (Fig. 2A), patients undergoing THA with pre-ALB $\geq 35 \mathrm{~g} / \mathrm{L}$ (Fig. 2B), patients undergoing TKA with pre-ALB $<35 \mathrm{~g} / \mathrm{L}$ (Fig. 2C), and patients undergoing TKA with pre-ALB $\geq 35 \mathrm{~g} / \mathrm{L}$ (Fig. 2D). Preoperative anemia (OR 2.12, 95\% Cl 1.34$3.36, \mathrm{P}=0.001$; OR 1.39, 95\% $\mathrm{Cl} 1.17-1.65, \mathrm{P}<0.001)$ and drain use (OR 3.33, 95\% $\mathrm{Cl} 1.60-6.93, \mathrm{P}=$ 0.001; OR 4.25, 95\% Cl 3.01-5.99, P < 0.001) were significant risk factors for HA administration following THA regardless pre-ALB $<35 \mathrm{~g} / \mathrm{L}$ or $\geq 35 \mathrm{~g} / \mathrm{L}$, while ASA class 2 (vs. 1, OR 1.68, 95\% Cl 1.38-2.05, P< $0.001)$ or 3 (vs. 1, OR 1.70, 95\% Cl 1.23-2.34, $\mathrm{P}=0.001)$, anticoagulant use (OR 2.16, 95\% Cl 1.31-3.56, $P=0.003$ ), and colloid solution use (OR 1.33, 95\% Cl 1.12-1.59, $P=0.001)$ were also significant risk factors for HA administration in patients undergoing THA with pre-ALB $\geq 35 \mathrm{~g} / \mathrm{L}$. 
For patients undergoing TKA, diagnosis of rheumatoid arthritis (RA) or ankylosing spondylitis (AS) was independent risk factor for HA administration regardless pre-ALB $<35 \mathrm{~g} / \mathrm{L}$ or $\geq 35 \mathrm{~g} / \mathrm{L}$ when compared with those patients with osteoarthritis (OR 3.67, 95\% Cl 1.60-8.40, P = 0.002; OR 2.06, 95\% Cl 1.38-3.07, $\mathrm{P}<0.001)$. Patients with $\mathrm{BMI} \geq 30 \mathrm{~kg} / \mathrm{m}^{2}(\mathrm{OR} 23.91,95 \% \mathrm{Cl} 3.07-186.02, \mathrm{P}=0.002)$ tended to receive $\mathrm{HA}$ administration than those with BMI between 18.5 and $24.9 \mathrm{~kg} / \mathrm{m}^{2}$ in pre-ALB $<35 \mathrm{~g} / \mathrm{L}$ group, whereas patients with drain use $(\mathrm{OR} 2.64,95 \% \mathrm{Cl} 1.62-4.30, \mathrm{P}<0.001)$ tended to receive HA administration in preALB $\geq 35 \mathrm{~g} / \mathrm{L}$ group.

\section{Discussion}

The most important finding of this large, multicenter, retrospective study was that the incidence of HA administration in patients undergoing THA or TKA was high, and several independent variables were risk factors for HA administration such as low pre-ALB levels, preoperative anemia, drain use, etc. To our knowledge, our study is the largest to date evaluating the independent risk factors associated with HA administration after THA or TKA. We focused specifically on variables of modifiable perioperative factors and demographic characteristics which help identify high-risk population. In addition, we used stratification analysis to eliminate potential contributions of pre-ALB level on other variables in the multivariate regression models. Because of this analysis, we believe there is an association between these discovered risk factors and HA administration after THA or TKA.

In the current study, the pre-ALB level was still the most important risk factor for HA administration, which can be modified by a series of interventions. Cao et al. [5] conducted a randomized controlled trial in which 162 patients undergoing primary TKA were recruited to receive either a new multimodal nutritional management or a traditional protocol. The multimodal nutritional management included multiple nutrition and protein powder before and after surgery, and it resulted in a lower rate and amount of HA administration, and shorter length of hospital stay. Moreover, in a similar prospective study that evaluated the effectiveness of perioperative essential amino acid supplementation, Ueyama et al. [4] demonstrated a significant increase in serum albumin with essential amino acid supplementation compared with placebo. A systematic review on the role of nutritional supplements in support of THA and TKA by Burgess et al. [13] concluded that optimizing nutritional status preoperatively may help manage the surgical stress response, with a particular benefit for undernourished, frail, or elderly individuals. Therefore, for patients with low pre-ALB levels, measures should be taken to optimize nutritional status, rather than just relying on $\mathrm{HA}$ administration.

The use of drain has been controversial in THA or TKA, with some advocated the use of drain because it reduced ecchymosis and avoided hematoma formation [14], while others had opposed the usage because it increased blood loss and prolonged postoperative length of stay [15]. In the current study, we found that the use of drain was an independent risk factor for HA administration after THA or TKA. This founding was failed in the group of patients undergoing TKA with pre-ALB $<35 \mathrm{~g} / \mathrm{L}$ due to the small sample size. However, there is no doubt that the use of drain would lead to an increased risk of HA administration because theoretically, drain use leads to the loss of proteins and nutrients while extracting 
the hemorrhage, which is disadvantageous to wound recovery [16]. Therefore, the use of drain during THA or TKA should be avoided or removed earlier since prolonged use is not necessary [17].

Preoperative anemia has been found to be a risk factor for blood transfusion after THA or TKA [12], and increase the cost [18], but little has confirmed the association between anemia and HA administration. In the current study, we found that preoperative anemia was an independent modifiable risk factor for $\mathrm{HA}$ administration after THA, regardless of pre-ALB $<35 \mathrm{~g} / \mathrm{L}$ or not, which has been confirmed before that anemia was associated with hypoalbuminemia [19]. In addition, we found that the incidence of anemia in patients undergoing THA was higher than those undergoing TKA, this may be related to that patients with hip fractures were included in the current study, because these patients were found to be with higher incidences of preoperative anemia, postoperative hypoalbuminemia, and HA administration [20]. Therefore, for patients undergoing THA with preoperative anemia, especially those with hip fractures, more attention should be paid to correct their anemia and nutritional status.

In the current study, we found that patients with inflammatory arthritis such as RA and AS tended to receive HA administration after TKA. Previous studies reported that active RA or AS patients were characterized by anemia and hypoalbuminemia [21, 22]. This may be associated with inflammation mediated by tumor necrosis factor- $a$ and interleukin-6, which decreased the expression of the albumin gene at the transcriptional level in the liver [23]. Another explanation may be that the permeability of the blood-joint barrier for albumin in RA patients is markedly increased, resulting in high albumin uptake at sites of inflammation [24]. This gives us a reminder for clinical work, that is, patients with RA or AS should pay more attention to nutritional status and albumin level, once hypoalbuminemia occurs, do an early intervention.

For patients undergoing THA with pre-ALB $\geq 35 \mathrm{~g} / \mathrm{L}$, ASA class 2 or 3 , anticoagulant use, and colloid solution use were also significant risk factors for HA administration after surgery. Patients with ASA class 2 or 3 usually have more comorbidities, which has been shown to be strongly associated with low postoperative albumin levels [3]. The use of anticoagulants may cause more hidden blood loss [25], leading to lower postoperative albumin levels. In contrast, revision surgery was not a risk factor for HA administration for either THA or TKA. It may be related to the small sample size in the current study. Besides, for patients undergoing revision surgery, the requirements were more strictly for patient screening and improvement of comorbidities, which may be one reason for no increased risk of HA administration after surgery of these patients.

There are several limitations in the current study. First, due to the small sample size, we should be cautious when understanding the positive result of $\mathrm{BMI} \geq 30 \mathrm{~kg} / \mathrm{m}^{2}$ as a risk factor of HA administration in the group of patients undergoing TKA with pre-ALB $<35 \mathrm{~g} / \mathrm{L}$, although malnutrition increased when the rates of obesity increased [3]. Second, patients in the current study were grouped into those with pre-ALB $<35 \mathrm{~g} / \mathrm{L}$ and those with pre-ALB $\geq 35 \mathrm{~g} / \mathrm{L}$, while patients were categorized into four groups: $<35 \mathrm{~g} / \mathrm{L}, 35$ to $<40 \mathrm{~g} / \mathrm{L}, 40$ to $<45 \mathrm{~g} / \mathrm{L}$, and $\geq 45 \mathrm{~g} / \mathrm{L}$ by Rudasill et al [9], and patients with hypoalbuminemia were categorized into quartiles: $<30 \mathrm{~g} / \mathrm{L}, 30$ to $31.9 \mathrm{~g} / \mathrm{L}, 32$ to $33.9 \mathrm{~g} / \mathrm{L}$, and 34 to $34.9 \mathrm{~g} / \mathrm{L}$ by Kishawi et al [3]. 
Therefore, we can't find the association between the albumin gradient and HA administration like other studies. Third, our study was limited by the number of available variables in the national database. The postoperative albumin levels were not routinely recorded in the database, while the incidence of HA administration was carefully recorded and easily collected. However, the decision of HA administration was not objective enough and the criteria were not very strict, this may bias our results. Finally, the study design was retrospective and observational, despite prospective data collection from the database. Prospective studies may be indicated to further confirm our findings.

\section{Conclusion}

The incidence of HA administration in patients undergoing THA or TKA was high, and pre-ALB $<35 \mathrm{~g} / \mathrm{L}$ and use of drain were modifiable risk factors for HA administration for patients undergoing either THA or TKA, while preoperative anemia, ASA class 2 or 3 , anticoagulant use, and colloid solution use were independent modifiable risk factors for HA administration after THA, and patients with RA or AS were high-risk population for receiving HA administration after TKA. Our predictive model based on available patient demographic characteristics and modifiable perioperative factors may aid surgeons in preoperatively identifying patients requiring $\mathrm{HA}$ administration and optimizing perioperative managements.

\section{Abbreviations}

AS: Ankylosing spondylitis; ASA: American Society of Anesthesiologists; BMI: Body mass index; Cl: Confidence interval; HA: Human albumin; OR: Odds ratio; Pre-ALB: Preoperative albumin; RA: Rheumatoid arthritis; THA: Total hip arthroplasty; TJA: Total joint arthroplasty; TKA: Total knee arthroplasty.

\section{Declarations}

\section{Acknowledgements}

The authors sincerely acknowledge the entire staffs of the Department of Orthopedics, West China Hospital, Sichuan University, who offered assistance in the coursing of this study. We also thank all the centers and surgeons who participated in the program.

\section{Authors' contributions}

SYZ conceived and designed the study, collected, analyzed, and interpreted the data, drafted the article, and gave final approval of manuscript. HBS, JWX, YGW and QSH collected, analyzed and interpreted the data, critically revised the article, and gave final approval of manuscript. YZ, FXP, and BS conceived and designed the study, critically revised the article, and gave final approval of manuscript.

\section{Finding}


No funding was obtained for this study.

\section{Availability of data and materials}

The datasets used and analyzed during the current study are available from the corresponding author on reasonable request.

\section{Ethical review statement:}

This retrospective study was approved by the institutional review board of West China Hospital, Sichuan University (2012-268). No informed consent was required since the data are anonymized.

\section{Consent for publication}

All authors have reviewed and approved the manuscript and are willing to attest to their qualifications as authors, disclose potential conflicts of interest, and release copyright should the manuscript be accepted for publication.

\section{Competing interests}

The authors declare that they have no conflict of interest, financial or otherwise.

\section{References}

1. Singh JA. Epidemiology of knee and hip arthroplasty: a systematic review. Open Orthop J. 2011;5:80-5.

2. George J, Chughtai M, Khlopas A, Klika AK, Barsoum WK, Higuera CA, et al. Readmission, Reoperation, and Complications: Total Hip vs Total Knee Arthroplasty. J Arthroplasty. 2018;33(3):655-60.

3. Kishawi D, Schwarzman G, Mejia A, Hussain AK, Gonzalez MH. Low Preoperative Albumin Levels Predict Adverse Outcomes After Total Joint Arthroplasty. J Bone Joint Surg Am. 2020;102(10):88995.

4. Ueyama H, Kanemoto N, Minoda Y, Taniguchi Y, Nakamura H. 2020 Chitranjan S. Ranawat Award: Perioperative essential amino acid supplementation suppresses rectus femoris muscle atrophy and accelerates early functional recovery following total knee arthroplasty. Bone Joint J 2020;102b(6_Supple_A):10 - 8.

5. Cao G, Huang Q, Xu B, Huang Z, Xie J, Pei F. Multimodal Nutritional Management in Primary Total Knee Arthroplasty: A Randomized Controlled Trial. J Arthroplasty. 2017;32(11):3390-5.

6. Sloan M, Sheth NP, Nelson CL. Obesity and hypoalbuminaemia are independent risk factors for readmission and reoperation following primary total knee arthroplasty. Bone Joint J 2020;102b(6_Supple_A):31 - 5. 
7. Wiedermann CJ. Phases of fluid management and the roles of human albumin solution in perioperative and critically ill patients. Curr Med Res Opin 2020:1.

8. Opperer M, Poeran J, Rasul R, Mazumdar M, Memtsoudis SG. Use of perioperative hydroxyethyl starch $6 \%$ and albumin $5 \%$ in elective joint arthroplasty and association with adverse outcomes: a retrospective population based analysis. Bmj. 2015;350:h1567.

9. Rudasill SE, Ng A, Kamath AF. Preoperative Serum Albumin Levels Predict Treatment Cost in Total Hip and Knee Arthroplasty. Clin Orthop Surg. 2018;10(4):398-406.

10. Wu XD, Zhu ZL, Xiao PC, Liu JC, Wang JW, Huang W. Are Routine Postoperative Laboratory Tests Necessary After Primary Total Hip Arthroplasty? J Arthroplasty. 2020;35(10):2892-8.

11. Xie J, Zhang S, Chen G, Xu H, Zhou Z, Pei F. Optimal route for administering tranexamic acid in primary unilateral total hip arthroplasty: Results from a multicenter cohort study. Br J Clin Pharmacol. 2019;85(9):2089-97.

12. Huang Z, Huang C, Xie J, Ma J, Cao G, Huang Q, et al. Analysis of a large data set to identify predictors of blood transfusion in primary total hip and knee arthroplasty. Transfusion. 2018;58(8):1855-62.

13. Burgess LC, Phillips SM, Wainwright TW. What Is the Role of Nutritional Supplements in Support of Total Hip Replacement and Total Knee Replacement Surgeries? A Systematic Review. Nutrients 2018;10(7).

14. Zhang QD, Guo WS, Zhang Q, Liu ZH, Cheng LM, Li ZR. Comparison between closed suction drainage and nondrainage in total knee arthroplasty: a meta-analysis. J Arthroplasty. 2011;26(8):1265-72.

15. Xu H, Xie J, Lei Y, Huang Q, Huang Z, Pei F. Closed suction drainage following routine primary total joint arthroplasty is associated with a higher transfusion rate and longer postoperative length of stay: a retrospective cohort study. J Orthop Surg Res. 2019;14(1):163.

16. Canbek U, Dibek E, Akgun U, Col B, Canbek TD, Aydogan NH, et al. Analysis of the fluid biochemistry in patients with prolonged wound drainage after hip hemiarthroplasty. Injury 2020.

17. Zhang S, Xu B, Huang Q, Yao H, Xie J, Pei F. Early Removal of Drainage Tube after Fast-Track Primary Total Knee Arthroplasty. J Knee Surg. 2017;30(6):571-6.

18. Schroer WC, Diesfeld PJ, LeMarr AR, Morton DJ, Reedy ME. Modifiable Risk Factors in Primary Joint Arthroplasty Increase 90-Day Cost of Care. J Arthroplasty. 2018;33(9):2740-4.

19. Röhrig G, Becker I, Polidori MC, Schulz RJ, Noreik M. Association of anemia and hypoalbuminemia in German geriatric inpatients: Relationship to nutritional status and comprehensive geriatric assessment. Z Gerontol Geriatr. 2015;48(7):619-24.

20. Wu XD, Liu JC, Li YJ, Wang JW, Qiu GX, Huang W. The necessity of routine postoperative laboratory tests after total hip arthroplasty for hip fracture in a semi-urgent clinical setting. J Orthop Traumatol. 2020;21(1):19.

21. Tsuji H, Hashimoto M, Harada T, Tanaka M, Ito H, Murakami K, et al. Persistent anemia and hypoalbuminemia in rheumatoid arthritis patients with low serum triiodothyronine level. Mod Rheumatol. 2020;30(4):640-7. 
22. Hu Y, Jiang WZ, Pan CL, Wang T. Active ankylosing spondylitis increases blood loss during total hip arthroplasty for a stiff hip joint. BMC Musculoskelet Disord. 2020;21(1):243.

23. Chojkier M. Inhibition of albumin synthesis in chronic diseases: molecular mechanisms. J Clin Gastroenterol. 2005;39(4 Suppl 2):143-6.

24. Kratz F. Albumin as a drug carrier: design of prodrugs, drug conjugates and nanoparticles. J Control Release. 2008;132(3):171-83.

25. Cui H, Chen K, Lv S, Yuan C, Wang Y. An analysis of perioperative hidden blood loss in femoral intertrochanteric fractures: bone density is an important influencing factor. BMC Musculoskelet Disord. 2021;22(1):6.

\section{Tables}

Table 1

Comparison of demographic characteristics and perioperative factors between HA and non-HA groups in patients underwent THA after stratified by preoperative serum albumin levels*. 


\begin{tabular}{|c|c|c|c|c|c|c|c|c|}
\hline \multirow[t]{2}{*}{ Variable } & \multicolumn{4}{|c|}{ Pre-ALB $<35 \mathrm{~g} / \mathrm{L}$} & \multicolumn{4}{|c|}{ Pre-ALB $\geq 35 \mathrm{~g} / \mathrm{L}$} \\
\hline & $\begin{array}{l}\text { Overall } \\
(n= \\
441)\end{array}$ & $\begin{array}{l}\mathrm{HA}(\mathrm{n} \\
=297)\end{array}$ & $\begin{array}{l}\text { No HA } \\
(n= \\
144)\end{array}$ & $\begin{array}{l}\text { P- } \\
\text { valuet }\end{array}$ & $\begin{array}{l}\text { Overall } \\
(\mathrm{n}= \\
4272)\end{array}$ & $\begin{array}{l}\text { HA (n } \\
= \\
661)\end{array}$ & $\begin{array}{l}\text { No HA } \\
(\mathrm{n}= \\
3611)\end{array}$ & $\begin{array}{l}\mathrm{P}- \\
\text { valuet }\end{array}$ \\
\hline Age (yrs) & & & & 0.593 & & & & 0.001 \\
\hline$\leq 64$ & $\begin{array}{l}253 \\
(57.4)\end{array}$ & $\begin{array}{l}175 \\
(69.2)\end{array}$ & $\begin{array}{l}78 \\
(30.8)\end{array}$ & & $\begin{array}{l}2932 \\
(68.6)\end{array}$ & $\begin{array}{l}414 \\
(14.1)\end{array}$ & $\begin{array}{l}2518 \\
(85.9)\end{array}$ & \\
\hline $65-79$ & $\begin{array}{l}137 \\
(31.1)\end{array}$ & $\begin{array}{l}90 \\
(65.7)\end{array}$ & $\begin{array}{l}47 \\
(34.3)\end{array}$ & & $\begin{array}{l}1194 \\
(27.9)\end{array}$ & $\begin{array}{l}219 \\
(18.3)\end{array}$ & $\begin{array}{l}975 \\
(81.7)\end{array}$ & \\
\hline$\geq 80$ & $\begin{array}{l}51 \\
(11.6)\end{array}$ & $\begin{array}{l}32 \\
(62.7)\end{array}$ & $\begin{array}{l}19 \\
(37.3)\end{array}$ & & $\begin{array}{l}146 \\
(3.4)\end{array}$ & $\begin{array}{l}28 \\
(19.2)\end{array}$ & $\begin{array}{l}118 \\
(80.8)\end{array}$ & \\
\hline Sex & & & & 0.069 & & & & 0.019 \\
\hline Male & $\begin{array}{l}205 \\
(46.5)\end{array}$ & $\begin{array}{l}147 \\
(71.7)\end{array}$ & $\begin{array}{l}58 \\
(28.3)\end{array}$ & & $\begin{array}{l}2015 \\
(47.2)\end{array}$ & $\begin{array}{l}284 \\
(14.1)\end{array}$ & $\begin{array}{l}1731 \\
(85.9)\end{array}$ & \\
\hline Female & $\begin{array}{l}236 \\
(53.5)\end{array}$ & $\begin{array}{l}150 \\
(63.6)\end{array}$ & $\begin{array}{l}86 \\
(36.4)\end{array}$ & & $\begin{array}{l}2257 \\
(52.8)\end{array}$ & $\begin{array}{l}377 \\
(16.7)\end{array}$ & $\begin{array}{l}1880 \\
(83.3)\end{array}$ & \\
\hline $\mathrm{BMI}\left(\mathrm{kg} / \mathrm{m}^{2}\right)$ & & & & 0.084 & & & & 0.120 \\
\hline$<18.5$ & $\begin{array}{l}45 \\
(10.2)\end{array}$ & $\begin{array}{l}31 \\
(68.9)\end{array}$ & $\begin{array}{l}14 \\
(31.1)\end{array}$ & & $\begin{array}{l}229 \\
(5.4)\end{array}$ & $\begin{array}{l}46 \\
(20.1)\end{array}$ & $\begin{array}{l}183 \\
(79.9)\end{array}$ & \\
\hline $18.5-24.9$ & $\begin{array}{l}281 \\
(63.7)\end{array}$ & $\begin{array}{l}178 \\
(63.3)\end{array}$ & $\begin{array}{l}103 \\
(36.7)\end{array}$ & & $\begin{array}{l}2639 \\
(61.8)\end{array}$ & $\begin{array}{l}412 \\
(15.6)\end{array}$ & $\begin{array}{l}2227 \\
(84.4)\end{array}$ & \\
\hline $25.0-29.9$ & $\begin{array}{l}103 \\
(23.4)\end{array}$ & $\begin{array}{l}78 \\
(75.7)\end{array}$ & $\begin{array}{l}25 \\
(24.3)\end{array}$ & & $\begin{array}{l}1184 \\
(27.7)\end{array}$ & $\begin{array}{l}176 \\
(14.9)\end{array}$ & $\begin{array}{l}1008 \\
(85.1)\end{array}$ & \\
\hline$\geq 30$ & $12(2.7)$ & $\begin{array}{l}10 \\
(83.3)\end{array}$ & $2(16.7)$ & & $\begin{array}{l}220 \\
(5.1)\end{array}$ & $\begin{array}{l}27 \\
(12.3)\end{array}$ & $\begin{array}{l}193 \\
(87.7)\end{array}$ & \\
\hline Diagnosis & & & & 0.008 & & & & 0.001 \\
\hline ONFH & $\begin{array}{l}157 \\
(35.6)\end{array}$ & $\begin{array}{l}108 \\
(68.8)\end{array}$ & $\begin{array}{l}49 \\
(31.2)\end{array}$ & & $\begin{array}{l}1420 \\
(33.2)\end{array}$ & $\begin{array}{l}179 \\
(12.6)\end{array}$ & $\begin{array}{l}1241 \\
(87.4)\end{array}$ & \\
\hline $\mathrm{DDH}$ & $25(5.7)$ & $\begin{array}{l}16 \\
(64.0)\end{array}$ & $9(36.0)$ & & $\begin{array}{l}842 \\
(19.7)\end{array}$ & $\begin{array}{l}125 \\
(14.8)\end{array}$ & $\begin{array}{l}717 \\
(85.2)\end{array}$ & \\
\hline OA & $\begin{array}{l}55 \\
(12.5)\end{array}$ & $\begin{array}{l}48 \\
(87.3)\end{array}$ & $7(12.7)$ & & $\begin{array}{l}872 \\
(20.4)\end{array}$ & $\begin{array}{l}161 \\
(18.5)\end{array}$ & $\begin{array}{l}711 \\
(81.5)\end{array}$ & \\
\hline HF & $\begin{array}{l}110 \\
(24.9)\end{array}$ & $\begin{array}{l}66 \\
(60.0)\end{array}$ & $\begin{array}{l}44 \\
(40.0)\end{array}$ & & $\begin{array}{l}394 \\
(9.2)\end{array}$ & $\begin{array}{l}69 \\
(17.5)\end{array}$ & $\begin{array}{l}325 \\
(82.5)\end{array}$ & \\
\hline Others & $\begin{array}{l}94 \\
(21.3)\end{array}$ & $\begin{array}{l}59 \\
(62.8)\end{array}$ & $\begin{array}{l}35 \\
(37.2)\end{array}$ & & $\begin{array}{l}744 \\
(17.4)\end{array}$ & $\begin{array}{l}127 \\
(17.1)\end{array}$ & $\begin{array}{l}617 \\
(82.9)\end{array}$ & \\
\hline ASA class & & & & 0.075 & & & & $<.001$ \\
\hline
\end{tabular}




\begin{tabular}{|c|c|c|c|c|c|c|c|c|}
\hline 1 & $\begin{array}{l}169 \\
(38.3)\end{array}$ & $\begin{array}{l}103 \\
(60.9)\end{array}$ & $\begin{array}{l}66 \\
(39.1)\end{array}$ & & $\begin{array}{l}1471 \\
(34.4)\end{array}$ & $\begin{array}{l}168 \\
(11.4)\end{array}$ & $\begin{array}{l}1303 \\
(88.6)\end{array}$ & \\
\hline 2 & $\begin{array}{l}226 \\
(51.2)\end{array}$ & $\begin{array}{l}162 \\
(71.7)\end{array}$ & $\begin{array}{l}64 \\
(28.3)\end{array}$ & & $\begin{array}{l}2461 \\
(57.6)\end{array}$ & $\begin{array}{l}430 \\
(17.5)\end{array}$ & $\begin{array}{l}2031 \\
(82.5)\end{array}$ & \\
\hline$\geq 3$ & $\begin{array}{l}46 \\
(10.4)\end{array}$ & $\begin{array}{l}32 \\
(69.6)\end{array}$ & $\begin{array}{l}14 \\
(30.4)\end{array}$ & & $\begin{array}{l}340 \\
(8.0)\end{array}$ & $\begin{array}{l}63 \\
(18.5)\end{array}$ & $\begin{array}{l}277 \\
(81.5)\end{array}$ & \\
\hline Anemia & & & & 0.002 & & & & $\begin{array}{l}< \\
0.001\end{array}$ \\
\hline Yes & $\begin{array}{l}212 \\
(48.1)\end{array}$ & $\begin{array}{l}158 \\
(74.5)\end{array}$ & $\begin{array}{l}54 \\
(25.5)\end{array}$ & & $\begin{array}{l}1725 \\
(40.4)\end{array}$ & $\begin{array}{l}318 \\
(18.4)\end{array}$ & $\begin{array}{l}1407 \\
(81.6)\end{array}$ & \\
\hline No & $\begin{array}{l}229 \\
(51.9)\end{array}$ & $\begin{array}{l}139 \\
(60.7)\end{array}$ & $\begin{array}{l}90 \\
(39.3)\end{array}$ & & $\begin{array}{l}2547 \\
(59.6)\end{array}$ & $\begin{array}{l}343 \\
(13.5)\end{array}$ & $\begin{array}{l}2204 \\
(86.5)\end{array}$ & \\
\hline Surgical type & & & & 0.835 & & & & 0.024 \\
\hline $\begin{array}{l}\text { Primary } \\
\text { unilateral }\end{array}$ & $\begin{array}{l}388 \\
(88.0)\end{array}$ & $\begin{array}{l}263 \\
(67.8)\end{array}$ & $\begin{array}{l}125 \\
(32.2)\end{array}$ & & $\begin{array}{l}3873 \\
(90.7)\end{array}$ & $\begin{array}{l}602 \\
(15.5)\end{array}$ & $\begin{array}{l}3271 \\
(84.5)\end{array}$ & \\
\hline $\begin{array}{l}\text { Primary } \\
\text { bilateral }\end{array}$ & 32 (7.3) & $\begin{array}{l}21 \\
(65.6)\end{array}$ & $\begin{array}{l}11 \\
(34.4)\end{array}$ & & $\begin{array}{l}221 \\
(5.2)\end{array}$ & $\begin{array}{l}23 \\
(10.4)\end{array}$ & $\begin{array}{l}198 \\
(89.6)\end{array}$ & \\
\hline $\begin{array}{l}\text { Revision } \\
\text { unilateral }\end{array}$ & $21(4.8)$ & $\begin{array}{l}13 \\
(61.9)\end{array}$ & $8(38.1)$ & & $\begin{array}{l}178 \\
(4.2)\end{array}$ & $\begin{array}{l}36 \\
(20.2)\end{array}$ & $\begin{array}{l}142 \\
(79.8)\end{array}$ & \\
\hline Anesthesia & & & & 0.028 & & & & 0.001 \\
\hline General & $\begin{array}{l}373 \\
(84.6)\end{array}$ & $\begin{array}{l}259 \\
(69.4)\end{array}$ & $\begin{array}{l}114 \\
(30.6)\end{array}$ & & $\begin{array}{l}3635 \\
(85.1)\end{array}$ & $\begin{array}{l}591 \\
(16.3)\end{array}$ & $\begin{array}{l}3044 \\
(83.7)\end{array}$ & \\
\hline $\begin{array}{l}\text { Spinal + } \\
\text { epidural + } \\
\text { CSE }\end{array}$ & $\begin{array}{l}68 \\
(15.4)\end{array}$ & $\begin{array}{l}38 \\
(55.9)\end{array}$ & $\begin{array}{l}30 \\
(44.1)\end{array}$ & & $\begin{array}{l}637 \\
(14.9)\end{array}$ & $\begin{array}{l}70 \\
(11.0)\end{array}$ & $\begin{array}{l}567 \\
(89.0)\end{array}$ & \\
\hline $\begin{array}{l}\text { Anticoagulant } \\
\text { use }\end{array}$ & & & & 0.040 & & & & 0.043 \\
\hline Yes & $\begin{array}{l}418 \\
(94.8)\end{array}$ & $\begin{array}{l}286 \\
(68.4)\end{array}$ & $\begin{array}{l}132 \\
(31.6)\end{array}$ & & $\begin{array}{l}4094 \\
(95.8)\end{array}$ & $\begin{array}{l}643 \\
(15.7)\end{array}$ & $\begin{array}{l}3451 \\
(84.3)\end{array}$ & \\
\hline No & $23(5.2)$ & $\begin{array}{l}11 \\
(47.8)\end{array}$ & $\begin{array}{l}12 \\
(52.2)\end{array}$ & & $\begin{array}{l}178 \\
(4.2)\end{array}$ & $\begin{array}{l}18 \\
(10.1)\end{array}$ & $\begin{array}{l}160 \\
(89.9)\end{array}$ & \\
\hline TXA use & & & & 0.758 & & & & 0.492 \\
\hline Yes & $\begin{array}{l}167 \\
(37.9)\end{array}$ & $\begin{array}{l}111 \\
(66.5)\end{array}$ & $\begin{array}{l}56 \\
(33.5)\end{array}$ & & $\begin{array}{l}2771 \\
(64.9)\end{array}$ & $\begin{array}{l}421 \\
(15.2)\end{array}$ & $\begin{array}{l}2350 \\
(84.8)\end{array}$ & \\
\hline No & $\begin{array}{l}274 \\
(62.1)\end{array}$ & $\begin{array}{l}186 \\
(67.9)\end{array}$ & $\begin{array}{l}88 \\
(32.1)\end{array}$ & & $\begin{array}{l}1501 \\
(35.1)\end{array}$ & $\begin{array}{l}240 \\
(16.0)\end{array}$ & $\begin{array}{l}1261 \\
(84.0)\end{array}$ & \\
\hline $\begin{array}{l}\text { Colloid } \\
\text { solution use }\end{array}$ & & & & 0.173 & & & & $\begin{array}{l}<.001 \\
0.001\end{array}$ \\
\hline
\end{tabular}




\begin{tabular}{|c|c|c|c|c|c|c|c|c|}
\hline Yes & $\begin{array}{l}292 \\
(66.2)\end{array}$ & $\begin{array}{l}203 \\
(69.5)\end{array}$ & $\begin{array}{l}89 \\
(30.5)\end{array}$ & & $\begin{array}{l}2349 \\
(55.0)\end{array}$ & $\begin{array}{l}418 \\
(17.8)\end{array}$ & $\begin{array}{l}1931 \\
(82.2)\end{array}$ & \\
\hline No & $\begin{array}{l}149 \\
(33.8)\end{array}$ & $\begin{array}{l}94 \\
(63.1)\end{array}$ & $\begin{array}{l}55 \\
(36.9)\end{array}$ & & $\begin{array}{l}1923 \\
(45.0)\end{array}$ & $\begin{array}{l}243 \\
(12.6)\end{array}$ & $\begin{array}{l}1680 \\
(87.4)\end{array}$ & \\
\hline Drain use & & & & 0.002 & & & & $\begin{array}{l}< \\
0.001\end{array}$ \\
\hline Yes & $\begin{array}{l}405 \\
(91.8)\end{array}$ & $\begin{array}{l}281 \\
(69.4)\end{array}$ & $\begin{array}{l}124 \\
(30.6)\end{array}$ & & $\begin{array}{l}3516 \\
(82.3)\end{array}$ & $\begin{array}{l}624 \\
(17.7)\end{array}$ & $\begin{array}{l}2892 \\
(82.3)\end{array}$ & \\
\hline No & $36(8.2)$ & $\begin{array}{l}16 \\
(44.4)\end{array}$ & $\begin{array}{l}20 \\
(55.6)\end{array}$ & & $\begin{array}{l}756 \\
(17.7)\end{array}$ & $\begin{array}{l}37 \\
(4.9)\end{array}$ & $\begin{array}{l}719 \\
(95.1)\end{array}$ & \\
\hline $\begin{array}{l}\text { Transfusion } \\
\text { use }\end{array}$ & & & & 0.970 & & & & 0.251 \\
\hline Yes & $\begin{array}{l}77 \\
(17.5)\end{array}$ & $\begin{array}{l}52 \\
(67.5)\end{array}$ & $\begin{array}{l}25 \\
(32.5)\end{array}$ & & $\begin{array}{l}792 \\
(18.5)\end{array}$ & $\begin{array}{l}112 \\
(14.1)\end{array}$ & $\begin{array}{l}680 \\
(85.9)\end{array}$ & \\
\hline No & $\begin{array}{l}364 \\
(82.5)\end{array}$ & $\begin{array}{l}245 \\
(67.3)\end{array}$ & $\begin{array}{l}119 \\
(32.7)\end{array}$ & & $\begin{array}{l}3480 \\
(81.5)\end{array}$ & $\begin{array}{l}549 \\
(15.8)\end{array}$ & $\begin{array}{l}2931 \\
(84.2)\end{array}$ & \\
\hline
\end{tabular}

*Data are reported as number (\%); †p-value calculated using Pearson chi-square test or Fisher exact test. ASA, American Society of Anesthesiologists; BMI, body mass index; CSE, combined spinal-epidural; DDH, development dysplasia of hip; HA, human albumin; HF, hip fracture; OA, osteoarthritis; ONFH, osteonecrosis of femoral head; Pre-ALB, preoperative albumin; THA, total hip arthroplasty; TXA, tranexamic acid.

Table 2

Comparison of demographic characteristics and perioperative factors between HA and non-HA groups in patients underwent TKA after stratified by preoperative serum albumin levels*. 


\begin{tabular}{|c|c|c|c|c|c|c|c|c|}
\hline \multirow[t]{2}{*}{ Variable } & \multicolumn{4}{|c|}{ Pre-ALB $<35 \mathrm{~g} / \mathrm{L}$} & \multicolumn{4}{|c|}{ Pre-ALB $\geq 35 \mathrm{~g} / \mathrm{L}$} \\
\hline & $\begin{array}{l}\text { Overall } \\
(n= \\
207)\end{array}$ & $\begin{array}{l}\mathrm{HA}(\mathrm{n} \\
=127)\end{array}$ & $\begin{array}{l}\text { No HA } \\
(n=80)\end{array}$ & $\begin{array}{l}P \text { - } \\
\text { valuet }\end{array}$ & $\begin{array}{l}\text { Overall } \\
(n= \\
4041)\end{array}$ & $\begin{array}{l}\text { HA (n } \\
= \\
283)\end{array}$ & $\begin{array}{l}\text { No HA } \\
(n= \\
3758)\end{array}$ & $\begin{array}{l}\mathrm{P} \text { - } \\
\text { valuet }\end{array}$ \\
\hline Age (yrs) & & & & 0.471 & & & & 0.205 \\
\hline$\leq 64$ & $\begin{array}{l}79 \\
(38.2)\end{array}$ & $\begin{array}{l}50 \\
(63.3)\end{array}$ & $\begin{array}{l}29 \\
(36.7)\end{array}$ & & $\begin{array}{l}1708 \\
(42.3)\end{array}$ & $\begin{array}{l}108 \\
(6.3)\end{array}$ & $\begin{array}{l}1600 \\
(93.7)\end{array}$ & \\
\hline $65-79$ & $\begin{array}{l}113 \\
(54.6)\end{array}$ & $\begin{array}{l}70 \\
(61.9)\end{array}$ & $\begin{array}{l}43 \\
(38.1)\end{array}$ & & $\begin{array}{l}2185 \\
(54.1)\end{array}$ & $\begin{array}{l}167 \\
(7.6)\end{array}$ & $\begin{array}{l}2018 \\
(92.4)\end{array}$ & \\
\hline$\geq 80$ & $15(7.2)$ & $\begin{array}{l}7 \\
(46.7)\end{array}$ & $8(53.3)$ & & $\begin{array}{l}148 \\
(3.7)\end{array}$ & $\begin{array}{l}8 \\
(5.4)\end{array}$ & $\begin{array}{l}140 \\
(94.6)\end{array}$ & \\
\hline Sex & & & & 0.376 & & & & 0.139 \\
\hline Male & $\begin{array}{l}59 \\
(28.5)\end{array}$ & $\begin{array}{l}39 \\
(66.1)\end{array}$ & $\begin{array}{l}20 \\
(33.9)\end{array}$ & & $\begin{array}{l}792 \\
(19.6)\end{array}$ & $\begin{array}{l}65 \\
(8.2)\end{array}$ & $\begin{array}{l}727 \\
(91.8)\end{array}$ & \\
\hline Female & $\begin{array}{l}148 \\
(71.5)\end{array}$ & $\begin{array}{l}88 \\
(59.5)\end{array}$ & $\begin{array}{l}60 \\
(40.5)\end{array}$ & & $\begin{array}{l}3249 \\
(80.4)\end{array}$ & $\begin{array}{l}218 \\
(6.7)\end{array}$ & $\begin{array}{l}3031 \\
(93.3)\end{array}$ & \\
\hline $\mathrm{BMI}\left(\mathrm{kg} / \mathrm{m}^{2}\right)$ & & & & 0.002 & & & & 0.115 \\
\hline$<18.5$ & $13(6.3)$ & $\begin{array}{l}9 \\
(69.2)\end{array}$ & $4(30.8)$ & & $74(1.8)$ & $\begin{array}{l}7 \\
(9.5)\end{array}$ & $\begin{array}{l}67 \\
(90.5)\end{array}$ & \\
\hline $18.5-24.9$ & $\begin{array}{l}103 \\
(49.8)\end{array}$ & $\begin{array}{l}59 \\
(57.3)\end{array}$ & $\begin{array}{l}44 \\
(42.7)\end{array}$ & & $\begin{array}{l}1637 \\
(40.5)\end{array}$ & $\begin{array}{l}125 \\
(7.6)\end{array}$ & $\begin{array}{l}1512 \\
(92.4)\end{array}$ & \\
\hline 25.0-29.9 & $\begin{array}{l}67 \\
(32.4)\end{array}$ & $\begin{array}{l}36 \\
(53.7)\end{array}$ & $\begin{array}{l}31 \\
(38.8)\end{array}$ & & $\begin{array}{l}1753 \\
(43.4)\end{array}$ & $\begin{array}{l}104 \\
(5.9)\end{array}$ & $\begin{array}{l}1649 \\
(94.1)\end{array}$ & \\
\hline$\geq 30$ & $\begin{array}{l}24 \\
(11.6)\end{array}$ & $\begin{array}{l}23 \\
(95.8)\end{array}$ & $1(4.2)$ & & $\begin{array}{l}577 \\
(14.3)\end{array}$ & $\begin{array}{l}47 \\
(8.1)\end{array}$ & $\begin{array}{l}530 \\
(91.9)\end{array}$ & \\
\hline Diagnosis & & & & 0.008 & & & & $<.001$ \\
\hline OA & $\begin{array}{l}158 \\
(76.3)\end{array}$ & $\begin{array}{l}88 \\
(55.7)\end{array}$ & $\begin{array}{l}70 \\
(44.3)\end{array}$ & & $\begin{array}{l}3678 \\
(91.0)\end{array}$ & $\begin{array}{l}229 \\
(6.2)\end{array}$ & $\begin{array}{l}3449 \\
(93.8)\end{array}$ & \\
\hline $\mathrm{RA}+\mathrm{AS}$ & $\begin{array}{l}41 \\
(19.8)\end{array}$ & $\begin{array}{l}32 \\
(78.0)\end{array}$ & $9(22.0)$ & & $\begin{array}{l}252 \\
(6.2)\end{array}$ & $\begin{array}{l}32 \\
(12.7)\end{array}$ & $\begin{array}{l}220 \\
(87.3)\end{array}$ & \\
\hline Others & $8(3.9)$ & $\begin{array}{l}7 \\
(87.5)\end{array}$ & $1(12.5)$ & & $\begin{array}{l}111 \\
(2.7)\end{array}$ & $\begin{array}{l}22 \\
(19.8)\end{array}$ & $\begin{array}{l}89 \\
(80.2)\end{array}$ & \\
\hline ASA class & & & & 0.092 & & & & 0.382 \\
\hline 1 & $\begin{array}{l}74 \\
(35.7)\end{array}$ & $\begin{array}{l}52 \\
(70.3)\end{array}$ & $\begin{array}{l}22 \\
(29.7)\end{array}$ & & $\begin{array}{l}1660 \\
(41.1)\end{array}$ & $\begin{array}{l}106 \\
(6.4)\end{array}$ & $\begin{array}{l}1554 \\
(93.6)\end{array}$ & \\
\hline 2 & $\begin{array}{l}110 \\
(53.1)\end{array}$ & $\begin{array}{l}60 \\
(54.5)\end{array}$ & $\begin{array}{l}50 \\
(45.5)\end{array}$ & & $\begin{array}{l}2087 \\
(51.6)\end{array}$ & $\begin{array}{l}153 \\
(7.3)\end{array}$ & $\begin{array}{l}1934 \\
(92.7)\end{array}$ & \\
\hline
\end{tabular}




\begin{tabular}{|c|c|c|c|c|c|c|c|c|}
\hline$\geq 3$ & $\begin{array}{l}23 \\
(11.1)\end{array}$ & $\begin{array}{l}15 \\
(65.2)\end{array}$ & 8 (34.8) & & $\begin{array}{l}294 \\
(7.3)\end{array}$ & $\begin{array}{l}24 \\
(8.2)\end{array}$ & $\begin{array}{l}270 \\
(91.8)\end{array}$ & \\
\hline Anemia & & & & 0.338 & & & & 0.012 \\
\hline Yes & $\begin{array}{l}77 \\
(37.2)\end{array}$ & $\begin{array}{l}44 \\
(57.1)\end{array}$ & $\begin{array}{l}33 \\
(42.9)\end{array}$ & & $\begin{array}{l}1111 \\
(27.5)\end{array}$ & $\begin{array}{l}96 \\
(8.6)\end{array}$ & $\begin{array}{l}1015 \\
(91.4)\end{array}$ & \\
\hline No & $\begin{array}{l}130 \\
(62.8)\end{array}$ & $\begin{array}{l}83 \\
(63.8)\end{array}$ & $\begin{array}{l}47 \\
(36.2)\end{array}$ & & $\begin{array}{l}2930 \\
(72.5)\end{array}$ & $\begin{array}{l}187 \\
(6.4)\end{array}$ & $\begin{array}{l}2743 \\
(93.6)\end{array}$ & \\
\hline Surgical type & & & & 0.060 & & & & 0.035 \\
\hline $\begin{array}{l}\text { Primary } \\
\text { unilateral }\end{array}$ & $\begin{array}{l}159 \\
(76.8)\end{array}$ & $\begin{array}{l}92 \\
(57.9)\end{array}$ & $\begin{array}{l}67 \\
(42.1)\end{array}$ & & $\begin{array}{l}3503 \\
(86.7)\end{array}$ & $\begin{array}{l}257 \\
(7.3)\end{array}$ & $\begin{array}{l}3246 \\
(92.7)\end{array}$ & \\
\hline $\begin{array}{l}\text { Primary } \\
\text { bilateral }\end{array}$ & $\begin{array}{l}42 \\
(20.3)\end{array}$ & $\begin{array}{l}32 \\
(76.2)\end{array}$ & $\begin{array}{l}10 \\
(23.8)\end{array}$ & & $\begin{array}{l}494 \\
(12.2)\end{array}$ & $\begin{array}{l}22 \\
(4.5)\end{array}$ & $\begin{array}{l}472 \\
(95.5)\end{array}$ & \\
\hline $\begin{array}{l}\text { Revision } \\
\text { unilateral }\end{array}$ & $6(2.9)$ & $\begin{array}{l}3 \\
(50.0)\end{array}$ & $3(50.0)$ & & $44(1.1)$ & $\begin{array}{l}4 \\
(9.1)\end{array}$ & $\begin{array}{l}40 \\
(90.9)\end{array}$ & \\
\hline Anesthesia & & & & 0.281 & & & & 0.040 \\
\hline General & $\begin{array}{l}151 \\
(72.9)\end{array}$ & $\begin{array}{l}96 \\
(63.6)\end{array}$ & $\begin{array}{l}55 \\
(36.4)\end{array}$ & & $\begin{array}{l}2883 \\
(71.3)\end{array}$ & $\begin{array}{l}217 \\
(7.5)\end{array}$ & $\begin{array}{l}2666 \\
(92.5)\end{array}$ & \\
\hline $\begin{array}{l}\text { Spinal + } \\
\text { epidural + } \\
\text { CSE }\end{array}$ & $\begin{array}{l}56 \\
(27.1)\end{array}$ & $\begin{array}{l}31 \\
(55.4)\end{array}$ & $\begin{array}{l}25 \\
(44.6)\end{array}$ & & $\begin{array}{l}1158 \\
(28.7)\end{array}$ & $\begin{array}{l}66 \\
(5.7)\end{array}$ & $\begin{array}{l}1092 \\
(94.3)\end{array}$ & \\
\hline $\begin{array}{l}\text { Tourniquet } \\
\text { use }\end{array}$ & & & & 0.401 & & & & 0.544 \\
\hline Yes & $\begin{array}{l}181 \\
(87.4)\end{array}$ & $\begin{array}{l}113 \\
(62.4)\end{array}$ & $\begin{array}{l}68 \\
(37.6)\end{array}$ & & $\begin{array}{l}3316 \\
(82.1)\end{array}$ & $\begin{array}{l}236 \\
(7.1)\end{array}$ & $\begin{array}{l}3080 \\
(92.9)\end{array}$ & \\
\hline No & $\begin{array}{l}26 \\
(12.6)\end{array}$ & $\begin{array}{l}14 \\
(53.8)\end{array}$ & $\begin{array}{l}12 \\
(46.2)\end{array}$ & & $\begin{array}{l}725 \\
(17.9)\end{array}$ & $\begin{array}{l}47 \\
(6.5)\end{array}$ & $\begin{array}{l}678 \\
(93.5)\end{array}$ & \\
\hline $\begin{array}{l}\text { Anticoagulant } \\
\text { use }\end{array}$ & & & & 0.566 & & & & 0.703 \\
\hline Yes & $\begin{array}{l}194 \\
(93.7)\end{array}$ & $\begin{array}{l}120 \\
(61.9)\end{array}$ & $\begin{array}{l}74 \\
(38.1)\end{array}$ & & $\begin{array}{l}3881 \\
(96.0)\end{array}$ & $\begin{array}{l}273 \\
(7.0)\end{array}$ & $\begin{array}{l}3608 \\
(93.0)\end{array}$ & \\
\hline No & $13(6.3)$ & $\begin{array}{l}7 \\
(53.8)\end{array}$ & $6(46.2)$ & & $\begin{array}{l}160 \\
(4.0)\end{array}$ & $\begin{array}{l}10 \\
(6.3)\end{array}$ & $\begin{array}{l}150 \\
(93.7)\end{array}$ & \\
\hline TXA use & & & & 0.652 & & & & 0.369 \\
\hline Yes & $\begin{array}{l}102 \\
(49.3)\end{array}$ & $\begin{array}{l}61 \\
(59.8)\end{array}$ & $\begin{array}{l}41 \\
(40.2)\end{array}$ & & $\begin{array}{l}2832 \\
(70.1)\end{array}$ & $\begin{array}{l}205 \\
(7.2)\end{array}$ & $\begin{array}{l}2627 \\
(92.8)\end{array}$ & \\
\hline No & $\begin{array}{l}105 \\
(50.7)\end{array}$ & $\begin{array}{l}66 \\
(62.9)\end{array}$ & $\begin{array}{l}39 \\
(37.1)\end{array}$ & & $\begin{array}{l}1209 \\
(29.9)\end{array}$ & $\begin{array}{l}78 \\
(6.5)\end{array}$ & $\begin{array}{l}1131 \\
(93.5)\end{array}$ & \\
\hline Colloid & & & & 0.822 & & & & 0.005 \\
\hline
\end{tabular}




\begin{tabular}{|c|c|c|c|c|c|c|c|c|}
\hline Yes & $\begin{array}{l}157 \\
(75.8)\end{array}$ & $\begin{array}{l}97 \\
(61.8)\end{array}$ & $\begin{array}{l}60 \\
(38.2)\end{array}$ & & $\begin{array}{l}2198 \\
(54.4)\end{array}$ & $\begin{array}{l}131 \\
(6.0)\end{array}$ & $\begin{array}{l}2067 \\
(94.0)\end{array}$ & \\
\hline No & $\begin{array}{l}50 \\
(24.2)\end{array}$ & $\begin{array}{l}30 \\
(60.0)\end{array}$ & $\begin{array}{l}20 \\
(40.0)\end{array}$ & & $\begin{array}{l}1843 \\
(45.6)\end{array}$ & $\begin{array}{l}152 \\
(8.2)\end{array}$ & $\begin{array}{l}1691 \\
(91.8)\end{array}$ & \\
\hline Drain use & & & & 0.381 & & & & $\begin{array}{l}<.001 \\
0.001\end{array}$ \\
\hline Yes & $\begin{array}{l}174 \\
(84.1)\end{array}$ & $\begin{array}{l}109 \\
(62.6)\end{array}$ & $\begin{array}{l}65 \\
(37.4)\end{array}$ & & $\begin{array}{l}3455 \\
(85.5)\end{array}$ & $\begin{array}{l}265 \\
(7.7)\end{array}$ & $\begin{array}{l}3190 \\
(92.3)\end{array}$ & \\
\hline No & $\begin{array}{l}33 \\
(15.9)\end{array}$ & $\begin{array}{l}18 \\
(54.5)\end{array}$ & $\begin{array}{l}15 \\
(45.5)\end{array}$ & & $\begin{array}{l}586 \\
(14.5)\end{array}$ & $\begin{array}{l}18 \\
(3.1)\end{array}$ & $\begin{array}{l}568 \\
(96.9)\end{array}$ & \\
\hline $\begin{array}{l}\text { Transfusion } \\
\text { use }\end{array}$ & & & & 0.124 & & & & 0.199 \\
\hline Yes & $\begin{array}{l}36 \\
(17.4)\end{array}$ & $\begin{array}{l}18 \\
(50.0)\end{array}$ & $\begin{array}{l}18 \\
(50.0)\end{array}$ & & $\begin{array}{l}789 \\
(19.5)\end{array}$ & $\begin{array}{l}47 \\
(6.0)\end{array}$ & $\begin{array}{l}742 \\
(94.0)\end{array}$ & \\
\hline No & $\begin{array}{l}171 \\
(82.6)\end{array}$ & $\begin{array}{l}109 \\
(63.7)\end{array}$ & $\begin{array}{l}62 \\
(36.3)\end{array}$ & & $\begin{array}{l}3252 \\
(80.5)\end{array}$ & $\begin{array}{l}236 \\
(7.3)\end{array}$ & $\begin{array}{l}3016 \\
(92.7)\end{array}$ & \\
\hline
\end{tabular}

*Data are reported as number (\%); †p-value calculated using Pearson chi-square test or Fisher exact test.

AS, ankylosing spondylitis; ASA, American Society of Anesthesiologists; BMI, body mass index; CSE, combined spinal-epidural; HA, human albumin; OA, osteoarthritis; Pre-ALB, preoperative albumin; RA, rheumatoid arthritis; TKA, total knee arthroplasty; TXA, tranexamic acid.

\section{Figures}




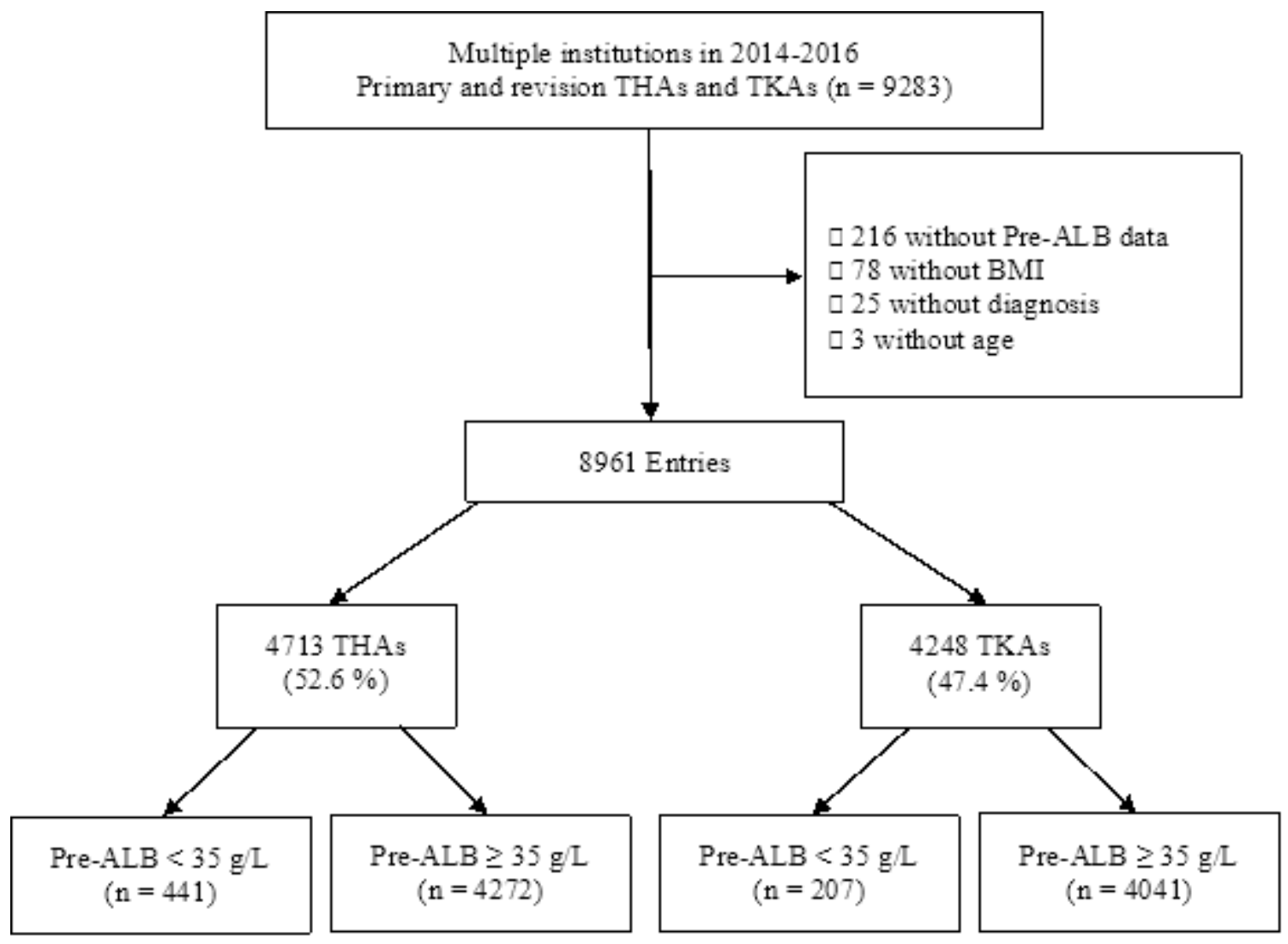

Figure 1

A flowchart shows the patient selection process. BMI, body mass index; Pre-ALB, preoperative albumin; THA, total hip arthroplasty; TKA, total knee arthroplasty.

A

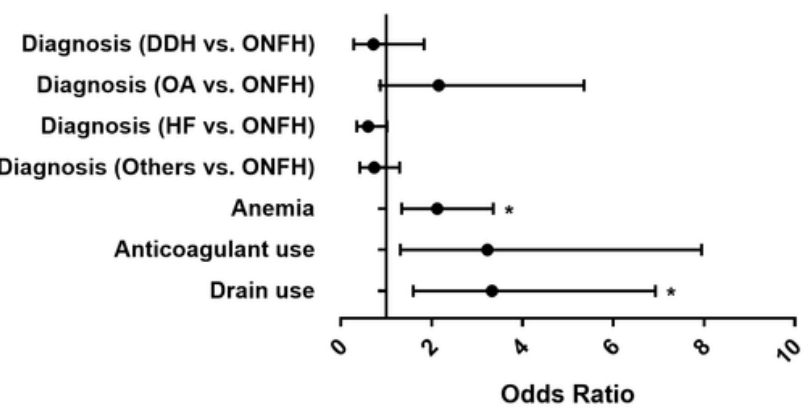

C

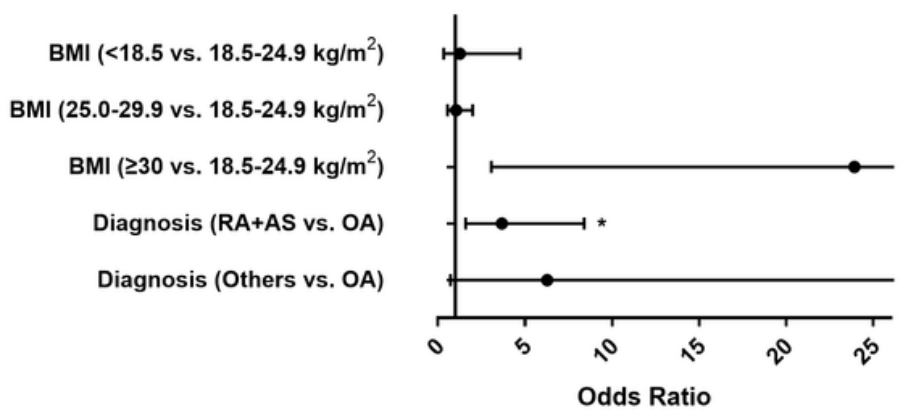

B

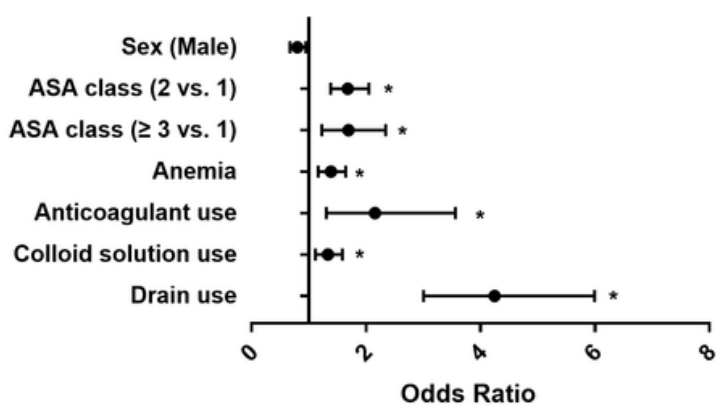

D

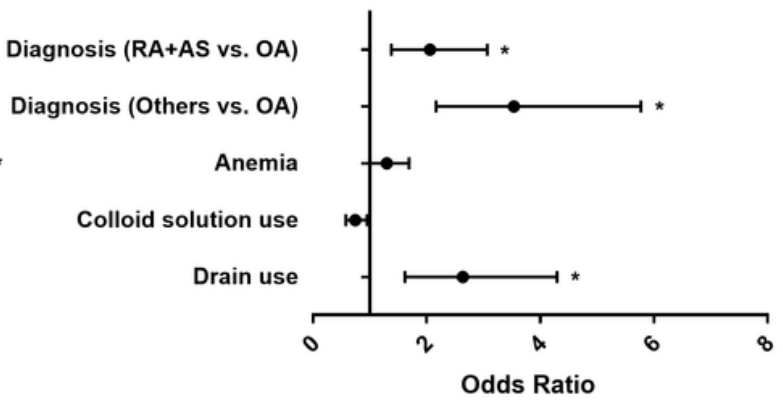


A-D Multivariable regression analysis of studied risk factors associated with human albumin administration in patients underwent THA with Pre-ALB $<35 \mathrm{~g} / \mathrm{L}(\mathrm{A})$, patients underwent THA with PreALB $\geq 35 \mathrm{~g} / \mathrm{L}$ (B), patients underwent TKA with Pre-ALB $<35 \mathrm{~g} / \mathrm{L}(\mathrm{C})$, and patients underwent TKA with Pre-ALB $\geq 35 \mathrm{~g} / \mathrm{L}(\mathrm{D})$. The results are shown as odds ratios with $95 \%$ confidence intervals. * indicates a significant difference after Bonferroni correction. AS, ankylosing spondylitis; ASA, American Society of Anesthesiologists; BMI, body mass index; DDH, development dysplasia of hip; HF, hip fracture; $\mathrm{OA}$, osteoarthritis; ONFH, osteonecrosis of femoral head; Pre-ALB, preoperative albumin; RA, rheumatoid arthritis; THA, total hip arthroplasty; TKA, total knee arthroplasty.

\section{Supplementary Files}

This is a list of supplementary files associated with this preprint. Click to download.

- Additionalfile1.Table1.doc

- Additionalfile1.Table2.doc 